\title{
Budesonide for the treatment of inflammatory bowel disease
}

\author{
GORDON R GREENBERG MD FRCPC
}

GR GREENBERG. Budesonide for the treatment of inflammatory bowel disease. Can J Gastroenterol 1994;8(6):369-372. While corticosteroids are the most effective treatment for the symptomatic management of patients with inflammatory bowel disease (IBD), they cause serious side effects. Budesonide is a nonhalogenated glucocorticosteroid structurally related to 16 alpha-hydroxyprednisolone that possesses high topical anti-inflammatory activity and low systemic activity compared with the conventional steroids prednisone and prednisolone. This favourable activity ratio is achieved because a high affinity to the steroid receptor is coupled with rapid hepatic conversion to metabolites with minimal or no biological activity. Controlled trials in patients with distal ulcerative colitis indicate that budesonide enemas have equivalent or superior efficacy compared with 5-aminosalicylic acid (5-ASA) enemas, prednisolone disodium phosphate enemas or methylprednisolone enemas, without causing significant depression of endogenous cortisol levels. Two controlled trials investigating the efficacy of an oral controlled-ileal release form of budesonide for active Crohn's disease have recently been completed. In the first trial, after eight weeks' treatment budesonide $9 \mathrm{mg}$ daily caused clinical remission in $51 \%$ of patients, compared with $20 \%$ of patients receiving placebo. Budesonide caused a dose-related reduction of plasma cortisol responses to adrenocorticotropic hormone stimulation, but was not associated with clinically important corticosteroid-related symptoms or other toxicity. In a second trial, budesonide $9 \mathrm{mg}$ daily was as effective as prednisolone for induction of remission in active ileocecal Crohn's disease. Budesonide is a potentially promising new therapeutic agent for the management of patients with IBD. (Pour résumé, voir page 370)

Key Words: Corticosteroids, Crohn's disease, Ulcerative colitis

Division of Gastroenterology, Mount Sinai Hospital, Department of Medicine, University of Toronto, Toronto, Ontario

Correspondence and reprints: Dr GR Greenberg, Mount Sinai Hospital, Room 445, 600 University Avenue, Toronto, Ontario M5G 1 X5. Telephone (416) 586-4727, Fax (416) $586-4802$

This paper was presented at the Trends in Inflammatory Bowel Disease Therapy meeting April 6 to 9, 1994, held in Victoria, British Columbia. This paper has also been published in Sutherland LR, et al, eds. Inflammatory Bowel Disease: Basic Research, Clinical Implications and Trends in Therapy. Boston, Dordrecht and London: Kluwer Academic Publishers, 1994
Orticosteroids REMAIN THE cornerstone of therapy for patients with acute inflammatory bowel disease (IBD). The efficacy of steroids has been shown when administered topically for distal ulcerative colitis (1) or systemically for panulcerative colitis (2), and for Crohn's disease involving the small bowel and/or colon $(3,4)$. However, the potentially serious side effects associated with corticosteroid treatment $(5,6)$ has prompted the search for new drugs that combine the advantages of high anti-inflammatory activity and a low adverse event profile. Budesonide, first developed for the treatment of asthma and allergic rhinitis (7), has recently been formulated into rectal and oral preparations for administration to patients with IBD. Initial results of this new corticosteroid suggest that, compared with conventional steroids, budesonide may have equivalent or superior efficacy for achieving clinical remission and fewer side effects.

\section{PHARMACOLOGICAL PROPERTIES OF BUDESONIDE}

Budesonide is a nonhalogenated glucocorticosteroid that is structurally related to $16 \alpha$-hydroxyprednisolone (Figure 1). The drug is a 1:1 mixture of two epimers designated $22 \mathrm{R}$ and $22 \mathrm{~S}$, 


\section{Budésonide dans le traitement de la maladie inflammatoire de l'intestin}

RÉSUMÉ : Bien que la corticothérapie soit le traitement le plus efficace des symptômes chez les patients atteints de maladie inflammatoire de l'intestin (MII), elle provoque de graves effets secondaires. Le budésonide est un glucocorticostéroïde non halogéné de structure apparentée à celle de la 16 alpha-hydroxyprednisolone, qui exerce une importante activité anti-inflammatoire topique et une faible activité systémique en comparaison avec les corticostéroïdes classiques prednisone et prednisolone. Ce ratio favorable d'activité est le fruit de sa grande affinité à l'endroit des récepteurs des stéroïdes, couplée à une rapide conversion hépatique en ses métabolites, le tout accompagné d'une activité biologique minime, voire nulle. Les essais contrôlés auprès de patients atteints de colite ulcéreuse distale indiquent que les lavements au budésonide sont d'une efficacité équivalente ou supérieure à celle des lavements à l'acide 5-aminosalicylique (5-AAS), au phosphate de prednisolone disodique ou à la méthylprednisolone, sans provoquer de dépression importante des taux endogènes de cortisol. Des essais contrôlés portant sur l'efficacité d'une formule de budésonide orale à libération contrôlée au niveau de l'iléon pour la maladie de Crohn active ont récemment pris fin. Dans le premier essai, après 8 semaines de traitement par budésonide $9 \mathrm{mg}$ par jour, une rémission clinique a été obtenue chez $51 \%$ des patients, contre $20 \%$ chez les patients sous placebo. Le budésonide a provoqué une réduction liée à la dose des réponses du cortisol plasmatique à la stimulation de l'hormone adrénocorticotrope, mais n'a pas été associé aux importants symptômes cliniques liés aux corticostéroïdes, ni à aucun autre signe de toxicité. Dans un deuxième essai, du budésonide $9 \mathrm{mg}$ par jour s'est révélé aussi efficace que la prednisolone à induire une rémission dans la maladie de Crohn iléo-caecale active. Le budésonide est un nouvel agent thérapeutique potentiellement prometteur pour le traitement des patients atteints de MII.

with the 22R epimer about three times more potent than the 22S epimer (8). Budesonide has high topical anti-inflammatory activity; the drug is about 200 fold more potent than hydrocortisone and, compared with prednisolone, has a 15 -fold greater affinity for the glucocorticosteroid receptor and a similarly greater anti-inflammatory activity (9). Compared with similar steroids, eg, fluticasone, budesonide is about 100 times more water soluble and relatively more lipid soluble, thus conferring not only adequate dissolution when administered orally or rectally but also effective absorption into the gut wall.

When administered as a rectal preparation, budesonide has a half-life of about 2 to 3 h. Only $2 \%$ of the drug, however, circulates; more than $95 \%$ is tissue-bound. After rectal administration, approximately $88 \%$ of budesonide is bound in the circulation to plasma proteins (10). Recently, budesonide has also been formulated into an enterocapsule for oral administration. This preparation is a gelatin capsule in which the drug is contained in multiple acid-stable microgranules (diameter of approximately $1 \mathrm{~mm}$ ) composed of an inner sugar core surrounded by a layer of budesonide in ethylcellulose and an outer coat of Eudragit L 100-55 that dissolves at $\mathrm{pH} 5.5$ or higher. Pharmacokinetic studies in healthy subjects indicate that after oral administration of this preparation the absorption of budesonide in the ileocecal region ranges between 52 and $79 \%$, with a mean absorption of $6.4 \mathrm{~h}$ and a systemic bioavailability of about $9 \%$ (11).

The $16 \alpha, 17 \alpha$ acetyl group of budesonide not only facilitates enhanced topical anti-inflammatory activity and stability in extrahepatic tissues but also confers about $90 \%$ firstpass hepatic metabolic to metabolites which possess minimal or no biological activity (12). The liver is the major site for steroid metabolism and produces two principal metabolites of budesonide, $16 \alpha$ hydroxyprednisolone and $6 \beta$-hydroxybudesonide, both of which have a glucocorticoid potency of less than $1 \%$ that of budesonide and a correspondingly much lower affinity for

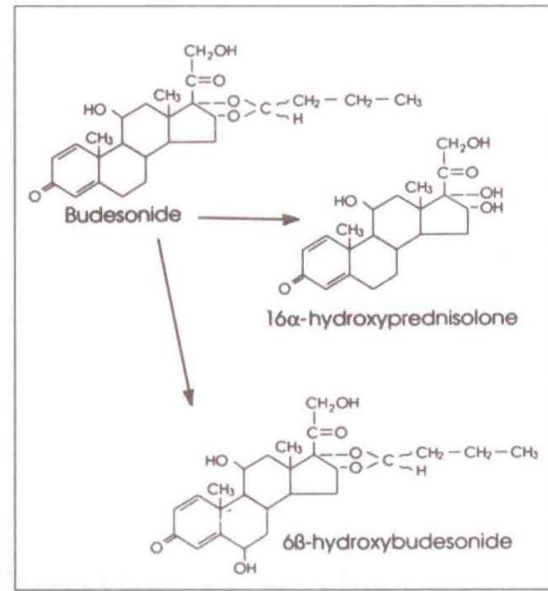

Figure 1) The chemical structure of budesonide and the principal metabolites in humans

the glucocorticoid receptor (Figure 1). A major fraction of these metabolites is excreted into the urine within $24 \mathrm{~h}$ of dosing, about one-third being excreted as conjugated metabolites. In contrast, prednisolone undergoes only about $20 \%$ first-pass liver metabolism.

\section{EFFICACY OF BUDESONIDE FOR DISTAL ULCERATIVE COLITIS}

Budesonide enemas comprise a tablet containing $2.3 \mathrm{mg}$ micronized budesonide and $1.66 \mathrm{mg}$ riboflavine phosphate (a yellow colorant to show dissolution) in a vehicle of $115 \mathrm{~mL}$ (isotonic sodium chloride and the preservatives methylhydroxy benzoate [ $80 \mathrm{mg}$ ] and propylhydroxybenzoate [20 mg]). The tablets are dissolved just before administration.

To date, nine clinical trials have evaluated the efficacy and safety of budesonide enemas for the treatment of distal ulcerative colitis. In one multicentre trial (13), 65 patients randomized to either prednisolone disodium phosphate $31.25 \mathrm{mg} / 100 \mathrm{~mL}$ or budesonide enemas containing $2 \mathrm{mg} /$ $100 \mathrm{~mL}$ administered for four weeks indicated $52 \%$ healing in patients receiving budesonide versus $24 \%$ healing in patients receiving prednisolone enemas. Patients receiving prednisolone enemas but not budesonide enemas had a significant depression of endogenous cortisol levels during the treatment period. A subsequent dose-ranging study (14) comparing prednisolone enemas 


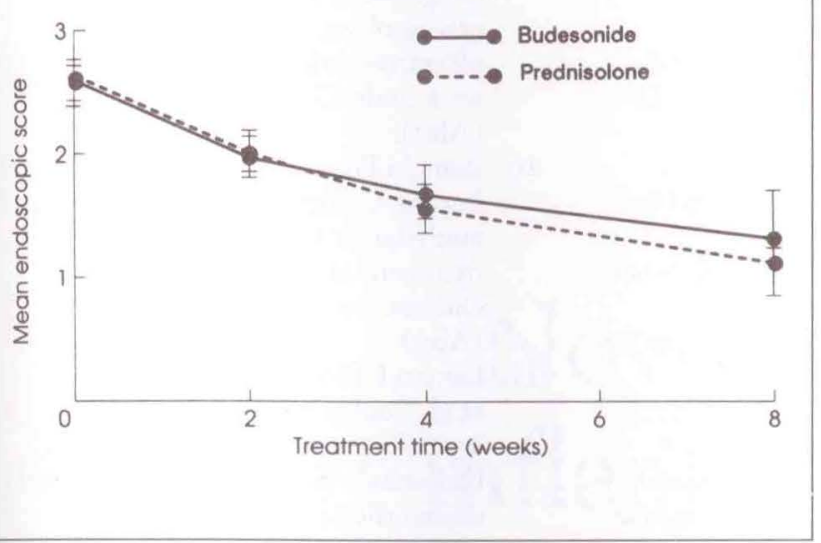

Figure 2) Effect of budesonide enemas versus prednisolone enemas on endoscopic scores (mean \pm SEM) in an eight-week study of patients with distal ulcerative colitis. Reproduced with permission from reference 15

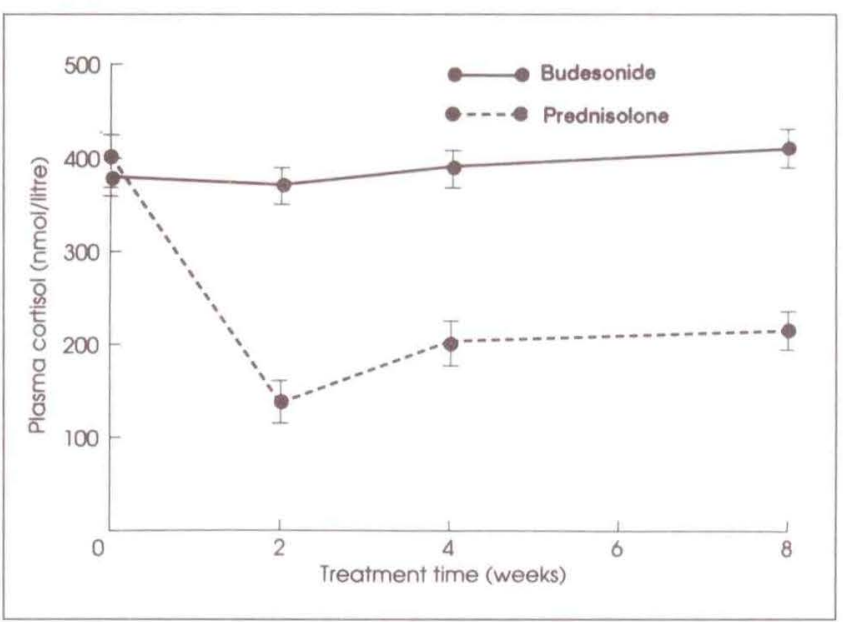

Figure 3) Effect of budesonide enemas versus prednisolone enemas on basal plasma cortisol levels (mean \pm SEM) in an eight-week study of patients with distal ulcerative colitis. Reproduced with permission from reference 15 with budesonide enemas containing either 1,2 or $4 \mathrm{mg} / 100 \mathrm{~mL}$ indicated that there were no statistically significant differences in treatment responses among the four groups, although budesonide $1 \mathrm{mg}$ tended to be least effective and budesonide $4 \mathrm{mg}$ was no more effective than the $2 \mathrm{mg}$ dose. Further multicentre trials $(15,16)$ have also shown that budesonide enemas were comparable to methylprednisolone $20 \mathrm{mg} / 100 \mathrm{~mL}$ enemas for achieving remission in patients with left-sided ulcerative colitis, (Figure 2), and without causing adrenal suppression (Figure 3). Moreover, serum osteocalcin showed a significantly greater decrease after methylprednisolone enemas compared with budesonide enemas (2.34 versus $1.07 \mu \mathrm{g} / \mathrm{L}, \mathrm{P}<0.05$ ) (15).

Budesonide enemas have also been evaluated against 5 -aminosalicylic acid (5-ASA) $4 \mathrm{~g}$ enemas in the treatment of left-sided ulcerative colitis $(17,18)$. In one trial (17) of 62 patients, both therapies improved the clinical symptom score, but the effect was greater in the 5-ASA group; sigmoidoscopic and histological scores were, however, equivalent in the two treatment groups. A further trial of 97 patients randomized to four weeks' therapy with budesonide enemas or 5-ASA $1 \mathrm{~g} / 100$ $\mathrm{mL}$ enemas showed that the two treatments produced equivalent endoscopic and histological scores (18).
Thus, in summary, budesonide enemas are at least as effective as prednisolone enemas for the treatment of left-sided ulcerative colitis, but with less adrenal suppression. The marginally greater efficacy of 5-ASA $4 \mathrm{~g} /$ $100 \mathrm{~mL}$ enemas compared with budesonide enemas suggests that budesonide enemas may be useful for left-sided ulcerative colitis patients who are refractory or intolerant to 5-ASA enemas.

\section{EFFICACY OF BUDESONIDE FOR ACTIVE CROHN'S DISEASE}

Recent formulation of budesonide into an enterocapsule preparation that facilitates delivery of the drug to the terminal ileum and proximal colon has led to two multicentre trials investigating the efficacy of the drug in patients with mild to moderately active ileocecal Crohn's disease. A multicentre trial undertaken in Canada (19) has shown that budesonide $9 \mathrm{mg}$ daily caused clinical remission in $51 \%$ of patients, compared with $20 \%$ in patients receiving placebo. Budesonide $15 \mathrm{mg}$ daily was no more effective than the $9 \mathrm{mg}$ dose. Budesonide in this trial caused a dose-related biochemical impairment of adrenal function measured by basal cortisol levels and responses to adrenocorticotropic hormone stimulation, but was not associated with clini- cally important corticosteroid-related symptoms or other toxicity. In a second European trial (20) of 10 weeks duration, budesonide $9 \mathrm{mg}$ was as effective as tapering doses of prednisolone (starting at $40 \mathrm{mg}$ daily) for induction of remission in active ileocecal Crohn's disease. In this latter trial, prednisolone caused a marginally greater reduction of the Crohn's disease activity index but was also associated with a significantly higher frequency of glucocorticoid-associated side effects. Further, the frequency of suppression of basal cortisol values in the European trial (20) after administration of budesonide $9 \mathrm{mg}$ once daily was less than in the Canadian trial (19) in which budesonide $9 \mathrm{mg}$ was provided as a divided twice-daily dose. Thus, budesonide $9 \mathrm{mg}$ given once daily appears to be the optimum dose for the management of acute ileocecal Crohn's disease.

\section{SUMMARY}

Budesonide appears to be a promising new drug for the management of patients with IBD. The role of long term budesonide administration for maintaining symptomatic remission in Crohn's disease and the value of an oral controlled colonic release preparation of budesonide for the treatment of panulcerative colitis remain areas of ongoing study. 


\section{REFERENCES}

1. Watkinson G. Treatment of ulcerative colitis with topical hydrocortisone sodium. A controlled trial employing restricted sequential analysis. Br Med J 1958;ii:1077-82.

2. Truelove SC, Witts LJ. Cortisone in ulcerative colitis. Final report on a therapeutic trial. Br Med J 1955;ii:104-8.

3. Summers RW, Switz DM, Sessions JT, et al. National Cooperative Crohn's Disease Study: Results of drug treatment. Gastroenterology 1979;77:847-69.

4. Malchow H, Ewe Y, Brandes JW, et al. European Cooperative Crohn's Disease Study (ECCDS): Results of drug treatment. Gastroenterology 1984;86:249-66.

5. Singleton JW, Law DH, Kelly ML Jr. National Cooperative Crohn's Disease Study: adverse reactions to study drugs. Gastroenterology 1979;77:870-82.

6. Compston JE, Judd D, Crowley EO, et al. Osteoporosis in patients with inflammatory bowel disease. Gut 1987;28:410-5.

7. Brogden RN, McTavish D. Budesonide. An updated review of its pharmacological properties and therapeutic efficacy in asthma and rhinitis. Drugs 1992;44:375-407.

8. Brattsand R. Overview of newer glucocorticosteroid preparation for inflammatory bowel disease. Can ] Gastroenterol 1990;4:407-14.

9. Johansson SA, Andersson KE, Brattsand R, Gruvstad E, Hedner P. Topical and systemic glucocorticoid potencies of budesonide, beclomethasone dipropionate and prednisolone in man. Eur J Resp Dis 1982;63(Suppl 122):74-82.

10. Davies D, Pauwels R. Pharmacokinetics and metabolism of budesonide, a selective glucocorticoid. Eur J Resp Dis 1982;63(Suppl 122): 86-95.

11. Edsbacker S, Wollmer P, Nilsson A, Nilsson M. Pharmacokinetics and gastrointestinal transit of budesonide controlled ileal release (CIR) capsules. Gastroenterology 1993;104:A695. (Abst)

12. Edsbacker S, Andersson P, Lindberg C, Paulson J, Ryrfeldt A, Thalen A. Liver metabolism of budesonide in rat, mouse and man. Drug Metab Dispos Biol Fate Chem 1987; 15:403-11.

13. Danielsson A, Hellers G, Lyrenas E, et al. A controlled randomized trial of budesonide versus prednisolone retention enemas in active distal ulcerative colitis. Scand J Gastroenterol 1987;22:987-92.

14. Danish Budesonide Study Group. Budesonide enema in distal ulcerative colitis. A randomized dose-response trial with prednisolone enema as positive control. Scand J Gastroenterol 1991;26:1225-30.
15. Lofberg R, Ostergaard-Thomsen O, Langholtz $\mathrm{E}$, et al. Budesonide versus prednisolone enema in active distal ulcerative colitis. A comparative eight week study. Gut 1993;34(Suppl 1):541. (Abst)

16. Bianchi Porro G, Campieri M, Bianchi $\mathrm{P}$, et al. Comparison of budesonide and methylprednisolone enemas in the treatment of ulcerative colitis. Gastroenterology 1992;102:A595. (Abst)

17. Lamers CBHW, Meijer J, Engels L, et al. Comparative study of the topically acting glucocorticosteroid budesonide and 5-aminosalicylic acid enema therapy of proctitis and proctosigmoiditis. Gastroenterology 1991;100:A223. (Abst)

18. Lemann M, Rutgeerts $P$, van Heuverzwijn R, et al. Comparison of budesonide enema and 5-ASA enema in the treatment of active distal ulcerative colitis. 1st United European Gastroenterology Week, Athens, September 25-30, 1992, Abstract 776.

19. Greenberg GR, Feagan BG, Martin F, et al. Oral budesonide for active Crohn's disease. N Engl J Med 1994;331:836-41.

20. Rutgeerts P, Löfberg R, Malchow H, et al. A comparison of budesonide with prednisolone for active Crohn's disease. N Engl J Med 1994:331:842-5. 


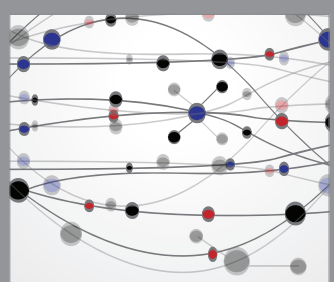

The Scientific World Journal
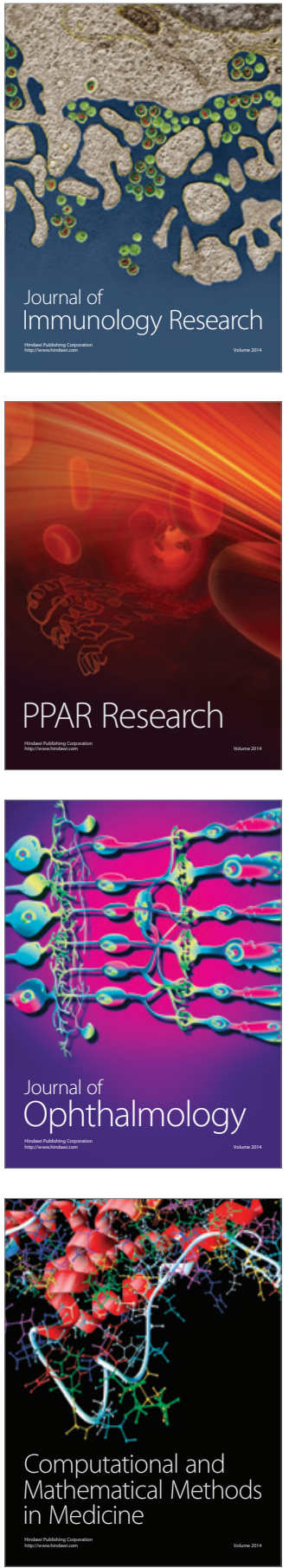

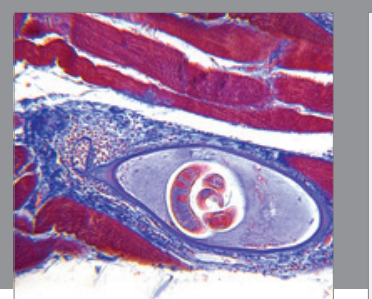

Gastroenterology Research and Practice

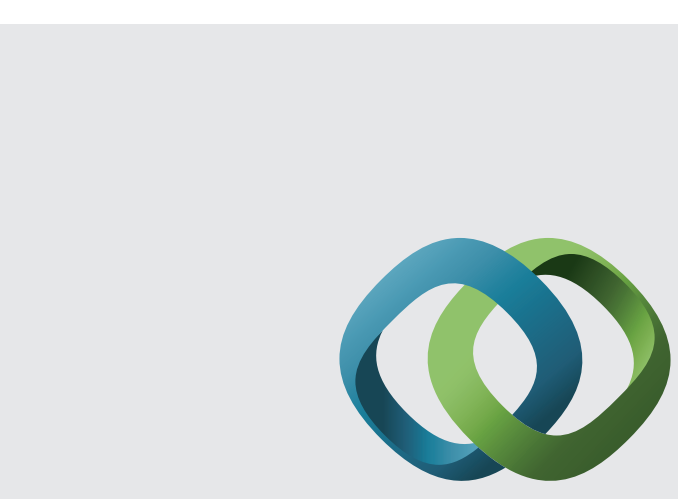

\section{Hindawi}

Submit your manuscripts at

http://www.hindawi.com
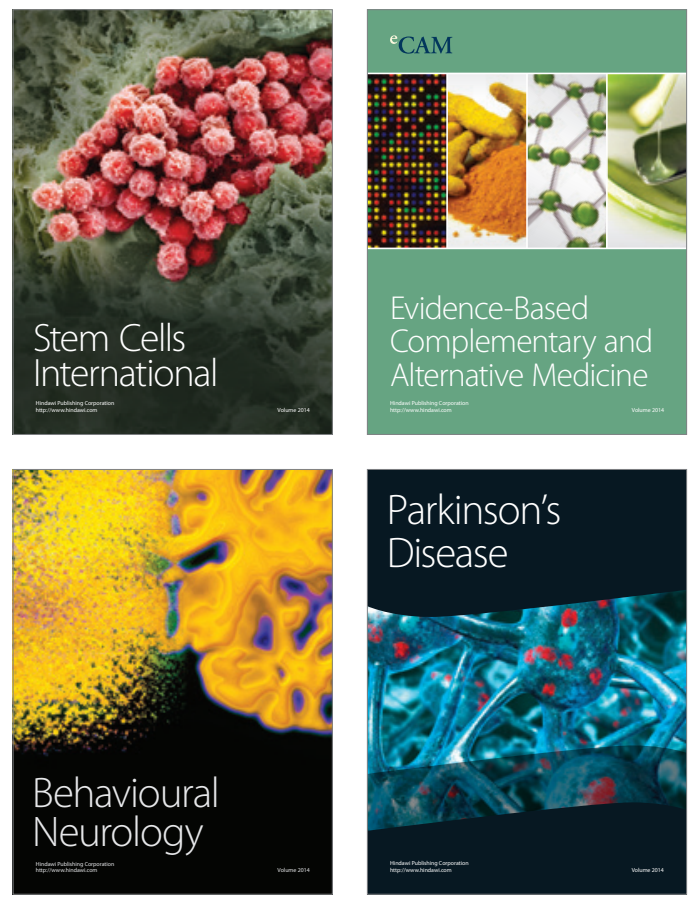
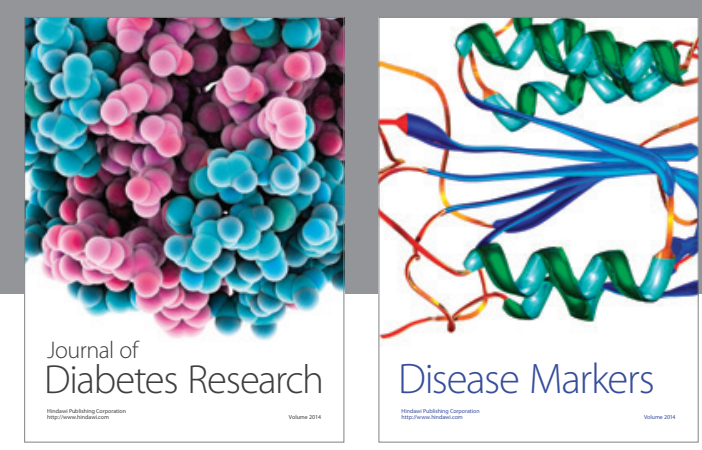

Disease Markers
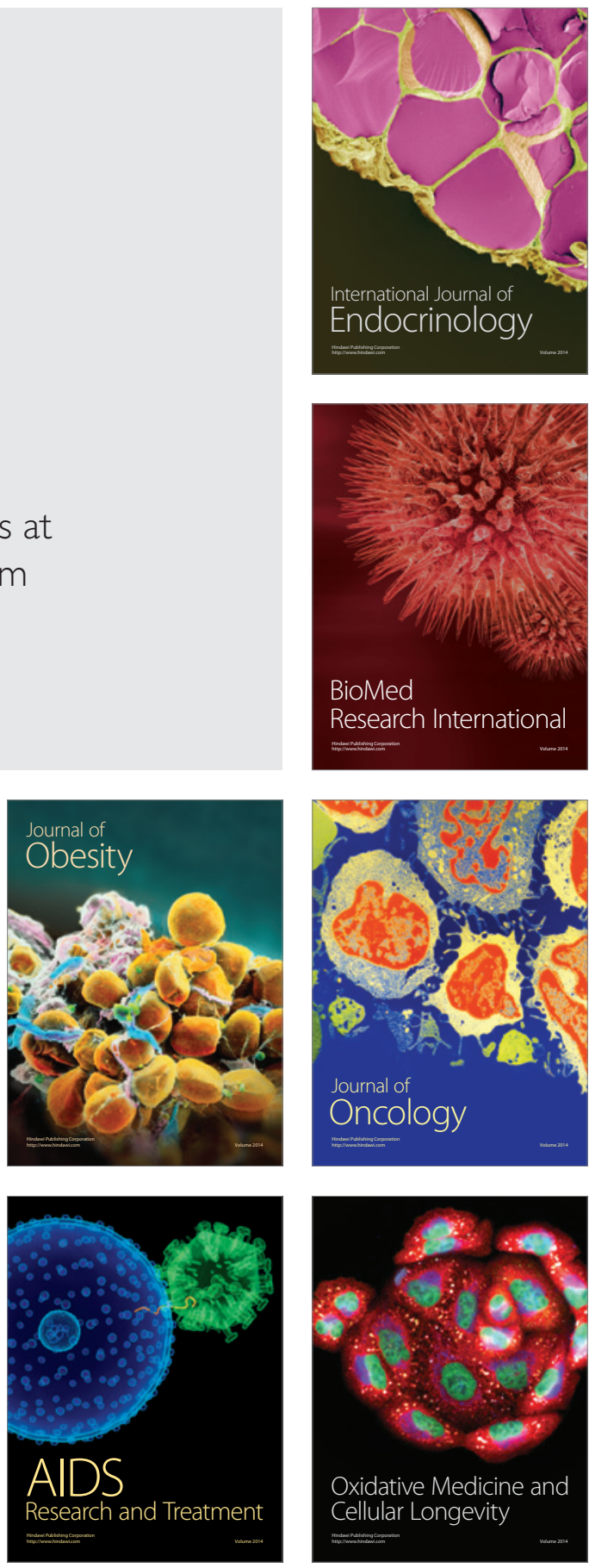